\title{
Reality of the Industrial Sector in Jordan
}

\author{
Dr. Ruba Abu Shihab* \\ Associated Professor, Al-Balqa Applied University, Jordan \\ Dr Eshaq M. AL Shaar \\ Associated Professor, Al-Blqa Applied University, Jordan \\ Dr .Hussameldin Daoud \\ Associated Professor, Muata University, Jordan
}

\section{The research is financed by Asian Development Bank. No. 2006-A171(Sponsoring information) \\ Abstract}

The study aims to examine Jordan's industrial sector by using descriptive statistical and econometric methods. For the purposes of analysis, we used a time series data for the Jordanian industrial sector (Mining, manufacturing, and electricity) from 1990 to 2017. The study came out of the importance of the Jordanian industrial sector. During the study period, the industrial sector ranked first among the sectors in terms of relative importance in its contribution to GDP at an annual average rate of $16 \%$. Comparing the industry's contribution to Jordan's GDP with other countries, Jordan is still relatively late compared to semi-industrialized developing countries, like Singapore, Indonesia, South Korea, Thailand, Malaysia, and Egypt. In addition, there was a fluctuating rise in labor productivity in the industrial sector, this may be due to the increase in the amount of fixed capital, as expressed by high capital intensity technology, or to the development of labor's skills and competencies. The study recommended the need to work to improve the output of the educational system in line with the requirements of revitalization of the industrial sector, and work to increase the efficiency of vocational training institutions in order to raise the productive efficiency of local labor because of the impact of the revitalization of the industrial sector. Keywords: industry, manufacturing, Mining, market, Jordan, electricity, Value added

DOI: $10.7176 / \mathrm{JESD} / 10-18-11$

Publication date:September $30^{\text {th }} 2019$

\section{Introduction}

The 1960s witnessed an increasing expansion of the industrialization movement in many developing countries. It has become clear to many economists and politicians in the developing world the importance of the role of industry in economic and social development, prompting some to argue that the industrial sector should be given priority as the main engine of growth and the essence of economic development.

The Jordanian industrial sector continued to develop and expand as a result of the government's interest on the one hand and the interest of the private sector on the other hand. The total industrial production in 2017 amounted to about (16.678) million, the total added value (7.582) million, and the number of industrial establishments and industrial services operating up to 95 thousand institutions with 160 thousand employees.

The industrial sector, which includes the extractive, electricity, and manufacturing industries, is one of the most important economic sectors as an indicator of the development of countries. It is the engine of growth and the essence of the economic development process, by increasing the growth rates of national income, and developing the production structure of the national economy (United Nation, 1955).

\section{Importance of research}

Given the importance of the industrial sector in the formation of the GDP and it's important for the success of economic development, it is necessary to recognize the percentage of this sector's contribution to the formation of the GDP, we can see that During the period 1990-2017, the industrial sector ranked first among commodity production sectors in terms of relative importance in its contribution to the GDP at an annual average of about $(16.1 \%)$. The sector ranked third among the economic sectors in most of the study years, after the financial services, insurance, real estate sector, and the government services sector, Where the industrial sector's compound annual growth rate was about (9.8\%) during the period 1990-2017.

Since the growth rate in the industrial sector is higher than the growth rate of GDP for the same period (7.3\%), the relative importance of the industrial sector increased from (13.5\%) in 1990 to (19.2\%) in 2017.

Comparing the industry's contribution to Jordan's GDP with other countries, Jordan is still relatively late compared to semi-industrialized developing countries, it was 24\% in Singapore. 26\%) in Indonesia and South Korea, 29\% in Thailand, 34\% in Malaysia and 25\% in Egypt in 2017. (World Bank, 2019). 


\section{The Hypothesis}

This research is based on the assumption that the Jordanian industrial sector occupies a leading position among other economic sectors.

\section{Research methodology}

The study was based on the primary sources of references that are examined in the subject of the study. The descriptive statistical and econometric methods was followed by analyzing the industrial sector and its development during the period 1990-2017.

\section{Previous Studies}

We can summarize some of the studies that dealt with the industrial sector as follows:

Basim Hasan (2017): This study aimed to analyze the importance of human capital, and to clarify its impact on both the industrial and macroeconomic sector in Jordan for the period from 1994 to 2014.This study concluded the importance of human capital in the economic growth in Jordan.

Al-Harazin et al. (2016) This study aimed to identify the reality of the transformational industry in Palestine and to identify the most important factors affecting labor productivity and wages in this sector during the period 1994-2012 through the use of modern statistical and measurement methods, where the results showed the Productivity and the average share of factor in investment in the manufacturing industry, the average share of compensation in the manufacturing sector and the inverse relationship between average productivity and facilities balances. On the other hand, the statistical results indicated that there is a direct relationship between the average productivity and the compensation of workers in the Palestinian manufacturing sector, and an inverse relationship between the compensation of workers in the manufacturing industry and inflation, whereas for the employment component in the labor market. The time variable, political, and economic instability have had a clear impact on both labor productivity and wages in the manufacturing sector.

Al-Bishtawi study, (2014): This study aimed at identifying the impact of intellectual capital on improving the profitability of Jordanian pharmaceutical companies. The study followed a descriptive approach. The study has reached many results, the most important of which are: Intellectual capital has a big and effective role in improving the life of Jordanian pharmaceutical companies. One of the most important recommendations of the study is the need to invest money in intellectual capital. To acquire cognitive resources and put $\mathrm{x}$ To preserve the intellectual capital through the programs of physical and moral stimulation and provide the right atmosphere and attract expertise, skills and competencies.

Abdul Moneim (2009): The study aimed to explore the concept of intellectual capital and its impact on raising the efficiency of Jordanian industrial companies, through the study of the case of ready-made clothes as a model for Jordanian industrial companies, as a leader in the clothes industry. This case study represents the practical aspect of the research. This study was conducted from a direct interview with a sample of the company's board members and owners as well as its financial managers. Jordanian ready-made clothes are confused between this concept and the concept of intellectual property, with the unclear impact of this concept on the efficiency of the company and its market value, as well as the lack of perception of how to measure and disclose in the financial statements, the study stressed the importance of intellectual capital in influencing the efficiency and value of the researched company. It also made it clear that its officials did not realize its great economic importance for its efficiency, value, growth and ways to benefit from it.

\section{Characteristics of the Jordanian industrial sector}

Industry in Jordan is divided into:

1- Manufacturing sector: it includes Leather and footwear manufacturing, chemical industry, Plastic industry, IT industry, Furniture industry, Food industry, Packaging industry, Engineering products manufacturing sector,....etc.. 2- Mining sector

3 Electricity industries

\section{Industry Sector Role in Gross Fixed Capital Formation}

The relative importance of fixed capital investments for the industrial sector for the period (1995-2006) reached about $8.75 \%$ of the total fixed capital formation, and it ranked third on average among all sectors after real estate activities and public administration.

The relative importance of the fixed capital formation of the industrial sector increased to $10.2 \%$ in 2017 , ranking fourth among all sectors after real estate activities, public administration, transport and storage, which led to the growth and development of the industrial sector during the period 2010-2017 (Central Bank of Jordan , 2018). 
Source: Department of Statistics, Annual Statistical Bulletin, various issues

\section{The Value added for the industry sector}

The development of industry value added figures directly reflects the essence of the manufacturing process. This expression is based on the fact that increasing the added value of industry means increasing the share of industrial surplus in the national economy and increasing the linkages of the industrial sector with other sectors of the economy. In other words, the growth of industrial value added reflects the evolution of the role of industry in the overall development process, especially in the field of national market formation and the development of selfresources and their exploitation in productive activities. However, the added value of industry in the national economy increased from JD (345.3) million in 1990 to JD (7581) million in 2017, thus achieving an annual growth rate of about (12\%) during the period.

It is worth mentioning that the statistical data on the development of value added of the industrial sector at current prices do not reflect the real increase in value added due to high prices and the spread of manifestations of inflation, which leads to an increase in value added without accompanied by an increase in the quantity of industrial output. And to know the real increase in value added GDP Deflator was used.

Excluding the impact of the high level of prices on the value added as shown in Table (1), it was found that the real value added increased from JD (224) million in 1990 to JD (712.2) million in 2017 with an annual growth rate of $(4.4 \%)$. 
Table (1) the Value Added of the Industry Sector and Annual Growth Rates in Jordan During the Period (1990-2017) (Value in million JD at cost)

\begin{tabular}{|c|c|c|c|c|}
\hline \multirow[t]{2}{*}{ Year } & \multicolumn{2}{|c|}{ Value Added at Fixed Prices * } & \multicolumn{2}{|c|}{ Added value at current prices } \\
\hline & growth rate $\%$ & Added value & growth rate \% & Added value \\
\hline 1990 & -0.7 & 224 & 36 & 345.3 \\
\hline 1991 & -0.1 & 220.7 & $\mathbf{0}$ & 343.7 \\
\hline 1992 & 15 & 253.7 & 18 & 406.3 \\
\hline 1993 & 0.3 & 261.9 & 0.5 & 427.3 \\
\hline 1994 & 2.9 & 336.8 & 31 & 561.7 \\
\hline 1995 & 0.1 & 340.3 & 0.3 & 579.7 \\
\hline 1996 & -0.9 & 309.7 & -0.9 & 528.6 \\
\hline 1997 & 0.4 & 323.5 & 12 & 592.1 \\
\hline 1998 & 0.3 & 332.7 & 0.3 & 609.8 \\
\hline 1999 & $\mathbf{0 . 2 7}$ & 456.4 & 14.7 & 9578 \\
\hline 2000 & 0.04 & 475.5 & -0.9 & 1013 \\
\hline 2001 & 0.2 & 597.4 & 0.31 & 1325 \\
\hline 2002 & 0.04 & 624.2 & 0.23 & 1633 \\
\hline 2003 & 0.13 & 718.6 & 0.13 & 1848 \\
\hline 2004 & 0.03 & 742.1 & 0.08 & 2001 \\
\hline 2005 & 0.02 & 754.5 & 0.06 & 2122 \\
\hline 2006 & -0 & 752.3 & 0.4 & 2965 \\
\hline 2007 & 0.06 & 796.9 & 0.05 & 3124 \\
\hline 2008 & -0.1 & 721.3 & 0.11 & 3463 \\
\hline 2009 & 0.01 & 727.9 & 0.16 & 4014 \\
\hline 2010 & 0.05 & 765.3 & 0.49 & 5964 \\
\hline 2011 & -0 & 754 & -0.2 & 4911 \\
\hline 2012 & 0.04 & 788 & -0.1 & 4562 \\
\hline 2013 & -0.1 & 702 & 0.04 & 4744 \\
\hline 2014 & 0.01 & 712 & 0.03 & 4877 \\
\hline 2015 & 0.04 & 745 & 0.37 & 6701 \\
\hline 2016 & -0 & 712 & 0.09 & 7311 \\
\hline 2017 & 0.02 & 725 & 0.04 & 7581 \\
\hline
\end{tabular}

* Estimated using GDP deflator (GDP Deflator 1995 = 100)

Source: Central Bank of Jordan, Annual Statistical Bulletin, various issues.

Excluding the impact of high prices on value added as shown in Table (1), the real value added increased from JD (224) million in 1990 to JD (712.2) million in 2017 with an annual growth rate of (4.4\%). Although the impact of the rise in prices on value added is excluded, there is still a general trend of increasing value added in real terms, which indicates that there are still other factors for the growth of industrial output.

The expansion of domestic demand contributes to increased manufacturing industrial output, Therefore, the impact of per capita income and population on the value added of the industrial sector was measured using the following statistical formula:

$\mathrm{Ln} \mathrm{V}=\mathrm{b}_{0}+\mathrm{b}_{1} \operatorname{Ln} \mathrm{Y}+\mathrm{b}_{2} \operatorname{Ln} \mathrm{P}+\mathrm{U} \ldots \ldots .(1)$

Where:

$\mathrm{V}$ : value added of the industry sector at constant prices.

$\mathrm{Y}$ : real per capita income where b1 is assumed to be positive.

$\mathrm{P}$ : population where $\mathrm{b} 2$ signal is assumed to be positive.

$\mathrm{U}$ : Random error limit

After estimating the previous equation by the least squares method (OLS) for the period (1990-2017, The results of the estimate are shown that the value added elasticity of income (b1) is about 1.05, In other words, if we assume that the population is constant, the rate of increase in the value added of the industrial sector exceeds the rate of increase in per capita income by $5 \%$. And The value added elasticity for the population (b2) is about 1.49 , ie, if we assume the per capita income stability, the rate of increase in value added for the industrial sector exceeds the rate of population increase by $49 \%$. Thus, it is clear to us that the importance of domestic demand in the growth of value added for the industrial sector through increasing per capita income and population.

\section{Per capita output of industry:}

The per capita output of industry is an important indicator to highlight the industry's ability to cope with population growth and contribute to the development of living standards. 
According to the estimation of per capita output of the industry, it was found that this share has registered remarkable increases. It increased at current prices from (130) dinars in 1995 to (651.3) dinars in 2017 at a compound annual growth rate of (7.6\%) during the study period. This reflects the ability of the industrial sector to achieve high growth rates at current prices that exceed the population growth rates.

Table (2) Per capita output of industry in Jordan during the period (1990-2017) (Value in million JD)

\begin{tabular}{|c|c|c|}
\hline Year & $\begin{array}{c}\text { Per capita value added at constant } \\
\text { prices } \\
(1995=100)\end{array}$ & $\begin{array}{c}\text { Per capita value added at current } \\
\text { prices }\end{array}$ \\
\hline 1990 & 62.7 & 97.5 \\
\hline 1991 & 59.6 & 92.9 \\
\hline 1992 & 66.8 & 106.9 \\
\hline 1993 & 65.6 & 107.1 \\
\hline 1994 & 78.5 & 136.0 \\
\hline 1995 & 79.3 & 135.1 \\
\hline 1996 & 69.8 & 119.1 \\
\hline 1997 & 70.3 & 128.7 \\
\hline 1998 & 70.0 & 128.2 \\
\hline 1999 & 71.2 & 130.4 \\
\hline 2000 & 72.2 & 133.2 \\
\hline 2001 & 74.3 & 134.5 \\
\hline 2002 & 75.6 & 130.4 \\
\hline 2003 & 79.2 & 145.2 \\
\hline 2004 & 81.2 & 150.2 \\
\hline 2005 & 77.2 & 142.2 \\
\hline 2006 & 82.6 & 155.6 \\
\hline 2007 & 89.2 & 170.2 \\
\hline 2008 & 94.2 & 174.2 \\
\hline 2009 & 92.4 & 172.3 \\
\hline 2010 & 91.2 & 171.2 \\
\hline 2011 & 86.2 & 164.3 \\
\hline 2012 & 85.4 & 161.2 \\
\hline 2013 & 82.1 & 154.2 \\
\hline 2014 & 80.2 & 150.3 \\
\hline 2015 & 78.2 & 142.2 \\
\hline 2016 & 78.0 & 140.2 \\
\hline 2017 & 76.5 & 132.4 \\
\hline 2018 & 76.7 & 134.2 \\
\hline
\end{tabular}

Source: Department of Statistics, Annual Statistical Bulletin, various issues

10. Contributions of the industrial sector in the employment of labor:

It is not enough to rely on the index of the contribution of the industrial sector to the GDP to determine the extent of the development of this sector, but it should also be referred to the workers in industrial activity relative to the total labor force. In the study of Table (3), it is noticeable on the one hand that the percentage of employed in agriculture sector decreased, where the percentage decreased from $(12.3 \%)$ in 1990 to $(4.7 \%)$ in 2018 . On the other hand, the percentage of employed in the industrial sector increased from (9.7\%) in 1990 to (13\%) in 2017. The number of employees increased from (54.3) thousand workers in 1990 to (156.56) thousand workers in 2017 with an annual growth rate of $(4 \%)$.

This pattern suggests, at first glance, a change in the structure of labor employment and shifting from agricultural to industrial activity as expected by development theories, but it should be noted that the proportion of workers in manufacturing and mining did not exceed more than $(11 \%)$ of the total workers in the economy Despite the great efforts made in the industrial sector.

Although the industrial sector in recent years has been ranked second among the economic sectors after the service sectors in terms of its contribution to the total number of employees, its contribution to the total number of employees is still low compared to the service sectors. This may be attributed to the shortage of qualified and trained technical cadres as a result of the migration of Jordanian labor to foreign markets, which led the industrial sector to rely on production methods with extensive use of capital because of the lack of qualified and trained hands. 
Table (3): Distribution of Total Employees in the Economic Sectors in Jordan During the Period (1990-2017)

\begin{tabular}{|c|c|c|c|c|c|c|c|c|c|c|c|}
\hline \multirow[t]{2}{*}{ Year } & \multicolumn{2}{|c|}{ Services } & \multicolumn{2}{|c|}{ Construction } & \multicolumn{2}{|c|}{$\begin{array}{l}\text { Electricity } \\
\text { and water }\end{array}$} & \multicolumn{2}{|c|}{$\begin{array}{c}\text { Manufacturing } \\
\text { and Mining }\end{array}$} & \multicolumn{2}{|c|}{ Farming } & \multirow{2}{*}{$\begin{array}{c}\text { Total } \\
\text { number } \\
\text { of } \\
\text { employees }\end{array}$} \\
\hline & $\%$ & Value & $\%$ & Value & $\%$ & Value & $\%$ & Value & $\%$ & Value & \\
\hline 1990 & 71.3 & 373.7 & 9.9 & 51.9 & 1.3 & 6.8 & 10.2 & 53.5 & 7.3 & 38.3 & 524.2 \\
\hline 1991 & 78.2 & 392.3 & 10.9 & 54.9 & 1.3 & 7.2 & 10.2 & 56.8 & 8.1 & 40.8 & 552.0 \\
\hline 1992 & 71.2 & 427.2 & 10.0 & 60.0 & 1.1 & 6.6 & 9.8 & 58.8 & 7.4 & 44.4 & 600.0 \\
\hline 1993 & 71.3 & 421.5 & 9.8 & 57.9 & 1.3 & 7.7 & 9.2 & 54.1 & 7.1 & 42.0 & 591.2 \\
\hline 1994 & 71.9 & 439.9 & 9.8 & 60.0 & 1.2 & 7.9 & 9.5 & 58.2 & 6.9 & 42.2 & 611.9 \\
\hline 1995 & 70.9 & 449.0 & 9.6 & 60.8 & 1.4 & 8.9 & 10.3 & 65.5 & 7.2 & 45.6 & 633.3 \\
\hline 1996 & 75.4 & 452.8 & 9.9 & 59.6 & 1.7 & 11.1 & 12.7 & 76.1 & 7.8 & 46.6 & 600.4 \\
\hline 1997 & 67.6 & 453.6 & 9.6 & 64.5 & 1.9 & 12.2 & 11.3 & 75.9 & 7.8 & 52.2 & 671.0 \\
\hline 1998 & 68.1 & 485.8 & 7.9 & 56.2 & 2.2 & 15.4 & 11 & 78.4 & 6.6 & 47 & 713.5 \\
\hline 1999 & 71.6 & 533.85 & 8.8 & 65.61 & 2.1 & 15.66 & 11 & 82.02 & 6.5 & 48.46 & 745.6 \\
\hline 2000 & 72.2 & 566.19 & 8.3 & 65.09 & 2 & 15.68 & 11.1 & 87.05 & 6.4 & 50.19 & 784.2 \\
\hline 2001 & 72.5 & 576.09 & 8.2 & 65.16 & 2 & 15.89 & 11.2 & 89 & 6.1 & 48.47 & 794.6 \\
\hline 2002 & 72.7 & 588.29 & 8 & 64.74 & 2.1 & 16.99 & 11.3 & 91.44 & 5.9 & 47.74 & 809.2 \\
\hline 2003 & 72.7 & 589.02 & 8 & 64.82 & 2.1 & 17.01 & 11.4 & 92.36 & 5.8 & 46.99 & 810.2 \\
\hline 2004 & 73 & 607.73 & 8 & 66.6 & 2 & 16.65 & 11.5 & 95.74 & 5.5 & 45.79 & 832.5 \\
\hline 2005 & 73.1 & 624.42 & 7.9 & 67.48 & 2 & 17.08 & 11.5 & 98.23 & 5.5 & 46.98 & 854.2 \\
\hline 2006 & 73 & 639.12 & 7.9 & 69.16 & 2 & 17.51 & 11.7 & 102.4 & 5.4 & 47.28 & 875.5 \\
\hline 2007 & 72.9 & 657.19 & 7.9 & 71.22 & 2.1 & 18.93 & 11.8 & 106.4 & 5.3 & 47.78 & 901.5 \\
\hline 2008 & 72.9 & 679.06 & 7.9 & 73.59 & 2 & 18.63 & 12.1 & 112.7 & 5.1 & 47.51 & 931.5 \\
\hline 2009 & 72.5 & 682.59 & 8.1 & 76.26 & 2 & 18.83 & 12.3 & 115.8 & 5.1 & 48.02 & 941.5 \\
\hline 2010 & 72.7 & 693.92 & 8 & 76.36 & 2.1 & 20.04 & 12.1 & 115.5 & 5.1 & 48.68 & 954.5 \\
\hline 2011 & 72.6 & 702.41 & 8 & 77.4 & 2.1 & 20.32 & 12.3 & 119 & 5 & 48.38 & 967.5 \\
\hline 2012 & 72.6 & 714.67 & 8 & 78.75 & 2.1 & 20.67 & 12.3 & 121.1 & 5 & 49.22 & 984.4 \\
\hline 2013 & 71.9 & 721.01 & 8 & 80.22 & 1.9 & 19.05 & 13.2 & 132.4 & 5 & 50.14 & 1002.8 \\
\hline 2014 & 72.6 & 794.39 & 8 & 87.54 & 2.1 & 22.98 & 12.4 & 135.7 & 4.9 & 53.62 & 1094.2 \\
\hline 2015 & 72.5 & 797.65 & 8.1 & 89.12 & 2 & 22 & 12.5 & 137.5 & 4.9 & 53.91 & 1100.2 \\
\hline 2016 & 72.5 & 803.37 & 8.1 & 89.76 & 2 & 22.16 & 12.7 & 140.7 & 4.7 & 52.08 & 1108.1 \\
\hline 2017 & 72.3 & 801.95 & 8.1 & $\mathbf{8 9 . 8 5}$ & 2 & 22.18 & 12.9 & 143.1 & 4.7 & 52.13 & 1109.2 \\
\hline
\end{tabular}

Source: Central Bank of Jordan, Annual Statistical Bulletin, various issues

\section{Worker productivity in the industrial sector}

The factor productivity index is one of the qualitative indicators that can identify the development of industry in this study, where the productivity is a scale which to measure the degree of exploitation of productive resources, as it means "the contribution of one worker in the generation of value added in industry", i.e., it reflects the relationship Between the output and the number of employees.

Labor productivity per worker in a given period can be identified by the relationship between output (value added) divided by the number of workers during the specified time period. Labor productivity is organically linked and depends on a workforce equipped with a certain technical level operating within a specific management system. In general, there are a number of factors affecting the productivity of labor, including mainly: the amount of machinery available, the nature of the equipment used, the level of knowledge, technical qualification of the worker, and the system of wages and bonuses.

It is noted from table (4), that the productivity of workers in the industrial sector (including manufacturing and mining) rose from (4186.9) dinars in 1990 to (5786.9) dinars in 2010 and decreased to (4243.6) dinars in 2017.

In general, there is an increase in labor productivity in the industrial sector during the period 1990-2010; this may be due to the increase in the amount of fixed capital, or expressed as a technique with high capital density, or to the development of human capital and skills of workers.

It should be noted that the ratio of workers in the industrial sector to the total number of workers in the economy cannot continue to grow much. This is because the professional distribution of workers is actually a dependent variable of consumption on the one hand and progress on the other hand.

This can be illustrated as follows:

Labor productivity $=$ The output/ Number of employees

We can also say:

Number of employees $=$ The output $/$ productivity 
Because output Parallels consumption, where the demand for labor is a derived demand from the demand for products, and here demand affect and determine the demand for labor:

Number of employees $=$ Consumption/ productivity

Consequently, the number of workers in a particular sector depends on the increase in both consumption and productivity, and it is known that in the advanced stages of economic development, the elasticity of demand for the products of the industrial sector is less than the elasticity of demand for services. Productivity in the industrial sector continues to rise due to continued technological advances. Indeed, continued technical advances will make labor productivity growth higher than consumption growth. Whereas, because of the difficulty of introducing a sophisticated machine into the service sector, demand for services exceeds the rate of labor productivity. Therefore, the number of workers in the industrial sector tends to decrease for the benefit of the services sector. The ratio of employees in this sector to the total number of employees will decrease in favor of the ratio of employees in the services sector to total employees.

Table (4) Worker Productivity in the Industrial Sector

\begin{tabular}{|c|c|c|c|}
\hline Year & $\begin{array}{l}\text { Number of employees } \\
\text { "Per thousand" }\end{array}$ & $\begin{array}{l}\text { Added value at constant prices } \\
\text { "Million JD" }\end{array}$ & $\begin{array}{l}\text { Worker productivity } \\
\text { "JD" }\end{array}$ \\
\hline 1990 & 53.5 & 224 & 4186.9 \\
\hline 1991 & 56.8 & 220.7 & 3885.6 \\
\hline 1992 & 58.8 & 253.7 & 4314.6 \\
\hline 1993 & 54.1 & 261.9 & 4841 \\
\hline 1994 & 58.2 & 336.8 & 5786.9 \\
\hline 1995 & 65.5 & 340.3 & 5195.4 \\
\hline 1996 & 76.1 & 309.7 & 4069.6 \\
\hline 1997 & 75.9 & 323.5 & 4262.2 \\
\hline 1998 & 78.4 & 332.7 & 4243.6 \\
\hline 1999 & 82.02 & 456.4 & 5564.5 \\
\hline 2000 & 87.05 & 475.5 & 5462.4 \\
\hline 2001 & 89 & 597.4 & 6712.4 \\
\hline 2002 & 91.44 & 624.2 & 6826.3 \\
\hline 2003 & 92.36 & 718.6 & 7780.4 \\
\hline 2004 & 95.74 & 742.1 & 7751.2 \\
\hline 2005 & 98.23 & 754.5 & 7681 \\
\hline 2006 & 102.4 & 752.3 & 7346.7 \\
\hline 2007 & 106.4 & 796.9 & 7489.7 \\
\hline 2008 & 112.7 & 721.3 & 6400.2 \\
\hline 2009 & 115.8 & 727.9 & 6285.8 \\
\hline 2010 & 115.5 & 765.3 & 6626 \\
\hline 2011 & 119 & 753.9 & 6335.3 \\
\hline 2012 & 121.1 & 788.4 & 6510.3 \\
\hline 2013 & 132.4 & 701.6 & 5299.1 \\
\hline 2014 & 135.7 & 712.1 & 5247.6 \\
\hline 2015 & 137.5 & 745.3 & 5420.4 \\
\hline 2016 & 140.7 & 712.2 & 5061.8 \\
\hline 2017 & 143.1 & 725 & 5066.4 \\
\hline
\end{tabular}

Source: Department of Statistics, Annual Statistical Bulletin, various issues

Source: Researcher

\section{Results and Recommendations}

From the above analysis the following conclusions can be drawn:

1- During the study period, the industrial sector ranked first among the commodity production sectors in terms of relative importance in its contribution to GDP at an annual average of about $(16.1 \%)$. Therefore, the relative importance of the industrial sector increased from (13.5\%) in 1990 to $(19.2 \%)$ in 2018.

2 - It is clear to us that the importance of domestic demand in the growth of value added for the industrial sector through increasing per capita income and population.

3- Comparing the industry's contribution to Jordan's GDP with other countries, Jordan is still relatively late compared to semi-industrialized developing countries, like Singapore, Indonesia, South Korea, Thailand, Malaysia, and Egypt.

4- The relative importance of the fixed capital formation of the industrial sector rose to $10.2 \%$, ranking fourth among all sectors after real estate activities, public administration, transport and storage, which led to the growth 
and development of the industrial sector during the period 2010-2017.

5.An estimate of per capita output of industry found that this share has registered remarkable increases, as it increased at current prices from (130) dinars in 1995 to (400) dinars in 2018 at a compound annual growth rate of (7.6\%) during the study period. This reflects the ability of the industrial sector to achieve high growth rates at current prices that exceed the population growth rates.

6- The percentage of employed in the industrial sector has increased from $9.7 \%$ in 1990 to $13 \%$ in 2017 , and the number of employees increased from 54.3 thousand in 1990 to 95.4 thousand in 2017 with an annual growth rate of $4 \%$.

7- Overall, there is a fluctuating rise in worker productivity in the industrial sector this is due to the increase in the amount of fixed capital, or expressed as a technique with high capital density, or to the development of skills and competencies in productive work.

In light of the study results, the study recommends the following :

1. Both the current and subsequent governments should pay attention to the industrial sector and make plans to achieve the highest possible growth rates in order to achieve growth as a welfare indicator.

2 - The need to work to improve the outputs of the educational system in line with the requirements of revitalization of the industrial sector.

3 - Work to increase the efficiency of vocational training institutions and increase the absorptive capacity in order to raise the productive efficiency of local labor because of the impact of the revitalization of the industrial sector.

4. Reviewing government policies related to the provision of permanent job opportunities as they lead to increase economic growth rates in the long term.

\section{References}

Abdelrahman Abushehab, (2019), The impact of human capital on the productivity of Jordanian industrial sector, Al-balqa Applied University, Jordan

Abdel Moneim, Osama, (2009), Intellectual Capital and its Impact on Industrial Businesses - Case Study 3 Jordan Readymade Garments Company, Jordan

Al-Nadi, Ali (1997)analysis of Total Factor Productivity in Jordanian Industrial Sector and The Effects of Foreign trade on It Master Thesis , University of Jordan Amman .

Al-Harazin, Hatem Al-Ra'ee, Mohammed (2016), Factors Affecting Labor Productivity and Wages in the Palestinian Manufacturing Sector During 1994-2012, Jordan Journal of Applied Sciences, Amman, Jordan.

Basim Abdul Fattah Mohammad Hasan (2017), The impact of human on total factor productivity of the industrial sector in Jordan (1994-2014), The University Of Jordan.

Bishtawi, Suleiman. Bani Taha, Ismail (2014), The Impact of Intellectual Capital on Improving the Profitability of Jordanian Pharmaceutical Industries, The Jordanian Journal of Business Administration, University of Jordan, Jordan

Central Bank of Jordan, Annual Statistical Bulletin, various issues

Department of Statistics, Annual Statistical Bulletin, various issues

Hashem Al-Dabbas, Jordan Industrial Policy Origin, Development, Achievement, Ministry of Industry and Trade, Jordan

World bank Statistics, various issues 